\title{
Mometasone furoate in the management of asthma: a review
}

\author{
Ricardo A Tan' \\ Jonathan Corren ${ }^{2}$ \\ 'California Allergy and Asthma \\ Medical Group, Los Angeles, CA; \\ ${ }^{2}$ Allergy Research Foundation, Los \\ Angeles, CA, USA
}

\begin{abstract}
Inhaled corticosteroids (ICS) have proven to be the most effective and essential therapy for the treatment of bronchial asthma. The 2007 National Asthma Education and Prevention Program guidelines recommend ICS as preferred therapy for patients with mild to severe persistent asthma. Mometasone furoate (MF) is a relatively new ICS agent with high affinity for the glucocorticoid receptor. It is approved in the US for maintenance treatment of asthma for patients 4 years of age and older. It has been shown to be well tolerated with no significant adverse side effects observed in clinical trials and post-marketing surveillance. The efficacy of mometasone furoate has been established in large, well-designed studies. In patients with persistent asthma previously treated either with short-acting beta-agonists alone or twice-daily maintenance therapy with ICS, once-daily MF has been shown to be superior to placebo in improving lung function, symptom control, and quality of life; and has shown comparable efficacy compared with budesonide, beclomethasone, and fluticasone. Twice-daily dosing with MF has been demonstrated to successfully allow for reduction or elimination of oral corticosteroids in severe asthmatics.
\end{abstract}

Keywords: inhaled steroids, mometasone furoate, once-daily dosing, asthma, stepwise approach

\section{Introduction}

Over the past two decades, inhaled corticosteroids (ICS) have been demonstrated to be the most effective treatment for persistent asthma. ICS act on the glucocorticoid receptor to inhibit the release of cytokines and inflammatory mediators, decrease eosinophil and mast cell recruitment, suppress adhesion molecule function and inducible nitric oxide synthase (National Heart, Lung and Blood Institute 2007). These cellular effects translate clinically into significant improvements in pulmonary function and asthma symptoms as well as reductions in exacerbations requiring oral corticosteroids, emergency room care, and hospitalization (National Heart, Lung and Blood Institute 2007). Further, this class of drugs has been demonstrated to be the most effective class of asthma medications compared with other drugs (National Heart, Lung and Blood Institute 2007). The most recent National Asthma Education and Prevention Program guidelines recommend ICS as preferred therapy for all severity levels of asthma (National Heart, Lung and Blood Institute 2007).

Mometasone furoate (MF) is the first ICS approved for once-daily dosing in the US and was approved for patients 12 years and older in 2005 and for children 4 to 11 years of age in 2008. It is marketed as Asmanex ${ }^{\mathrm{TM}}$ with $110 \mu \mathrm{g}$ and $220 \mu \mathrm{g}$ per actuation in a multidose dry powder breath-actuated device (Twisthaler ${ }^{\mathrm{TM}}$ ). The $220 \mu \mathrm{g}$ form delivers $200 \mu \mathrm{g}$ of mometasone furoate per actuation while the $110 \mu \mathrm{g}$ form delivers $100 \mu \mathrm{g}$ mometasone furoate per actuation. The recommended dosages are $220 \mu \mathrm{g}$ to $440 \mu \mathrm{g}$ once daily in the evening (or in 2 divided doses) for patients 12 years and older previously treated with either bronchodilators alone or with ICS. The recommended dose for 
patients requiring daily treatment with oral corticosteroids is $440 \mu \mathrm{g}$ twice daily. The only recommended dose for children 4 to 11 years is $110 \mu \mathrm{g}$ once daily in the evening.

\section{Chemistry}

MF is a synthetic, 17-heterocyclic conrticosteroid with a very high affinity for the glucocorticoid receptor. The chemical name of MF is $9 \alpha, 21$-dichloro- $11 \beta, 17 \alpha$-dihydroxy$16 \alpha$-methyl-pregna-1,4-diene-3,20-dione17-(2')-furoate. Its molecular formula is $\mathrm{C}_{27} \mathrm{H}_{30} \mathrm{O}_{6} \mathrm{Cl}_{2}$. In vitro studies show that $\mathrm{MF}$ binds to a monomeric glucocorticoid receptor at low concentrations and at high concentrations causes dimerization of the glucocorticoid receptor. The receptor affinity of MF has been estimated to be 12 times that of dexamethasone, 7 times that of triamcinolone acetonide, 5 times that of budesonide, and 1.5 times that of fluticasone (Crim et al 2001).

\section{Pharmacology}

MF is extensively metabolized in the liver by the CYP3A4 enzyme system with only a minor metabolite, $6 \beta$-hydroxyMF (Affrime and Kosoglu 2001). This metabolite is not detectable in plasma after single and multiple doses of MF- (dry powder inhaler) DPI, making it unlikely that it would affect the hydroxylation of other drugs metabolized by CYP3A4 (Karpel and Nelson 2007). In vitro studies have demonstrated that there may be as many as 5 metabolites and 4 degradation products of MF (Ten et al 2003; Sahasranaaman et al 2006). Study doses were mainly excreted in the feces with a small amount in the urine (74 \% and 8\% respectively) (Karpel and Nelson 2007). Pharmacologic studies of MF in which a single $1000 \mu \mathrm{g}$ dose of tritiated (3H-) MF was administered by DPI to healthy subjects showed that the plasma concentration were below the limit of quantification ( $\mathrm{LOQ}=50 \mathrm{pg} / \mathrm{mL}$ ) in $92 \%$ of subjects. These initial data suggested that the bioavailability of inhaled MF is less than 1\% (Affrime et al 2000). However, other investigations have indicated that the true bioavailability of MF is higher and similar in magnitude to that of other ICS (Derendorf et al 2002).

In vitro studies have demonstrated that MF has a very high binding affinity for human glucocorticoid receptor. Valotis et al (2004) showed that the relative receptor affinity for MF is 2200 compared with 100 for dexamethasone and 1800 for fluticasone propionate. In that same study, dissociation of the MF-receptor complex was faster than that observed for fluticasone, allowing for faster redistribution of the drug from lung tissue into the plasma. The relative receptor affinity of 6-beta-hydorxy MF has been shown to be significantly lower than the parent compound and is similar in activity to that of flunisolide (206 and 180 for MF and flunisolide, respectively) (Valotis and Högger 2004).

\section{Clinical efficacy (Table I) Once-daily dosing in patients only on SABAs}

Two randomized, double blind studies have confirmed the efficacy of once-daily dosing of MF-DPI compared with placebo in steroid-naïve patients only on SABAs.

In a study by Bensch et al (2006), 196 adult and adolescent asthmatics were randomized to either MF $200 \mu \mathrm{g}$ once daily in the evening or placebo for 12 weeks. The study demonstrated that MF was well tolerated and showed a significant improvement from baseline $\mathrm{FEV}_{1}$ of $0.43 \mathrm{~L}$ (16.8\%) compared with placebo of $0.16 \mathrm{~L}$ ( $6 \%)(\mathrm{p}<0.01)$. There was also significant improvement in forced vital capacity (FVC), forced expiratory flow (FEF) 25\% to $75 \%$, and peak expiratory flow (PEF) in the treatment group compared with placebo. There were no significant differences between the two groups in the time to worsening of asthma. Other efficacy variables of asthma symptom scores, rescue albuterol use, and nocturnal awakenings were also not significantly different in the two groups. The authors felt that the results showed that a relatively low dose of MF $200 \mu \mathrm{g}$ was significantly better than placebo in the steroid-naïve population.

In a second study of 236 steroid-naïve adolescent and adult asthmatics by Nayak et al (2000), 2 doses given once daily in the morning $(200 \mu \mathrm{g}$ and $400 \mu \mathrm{g})$ were compared with placebo assessments. The study results showed that both doses of MF were well-tolerated. For $\mathrm{FEV}_{1}$, both the $200 \mu \mathrm{g}$ and $400 \mu \mathrm{g}$ once-daily doses showed superior efficacy at $14.8 \%$ and $14.2 \%$ respectively, compared with placebo (2.5\%) but no significant difference between each other. Most of the secondary efficacy variables were significantly improved with both doses compared with placebo. An important finding was that the morning PEF was significantly superior to placebo with the $400 \mu \mathrm{g}$ dose but not with the $200 \mu \mathrm{g}$ dose. The authors suggested that $400 \mu \mathrm{g}$ should be the starting dose with reduction later likely to the $200 \mu \mathrm{g}$ dose (Nayak et al 2000).

\section{Once-daily versus twice-daily dosing in patients on SABAs only}

In a 12-week study by Kemp et al (2000) with 306 mild to moderate asthmatic subjects using inhaled SABAs only, MF given once daily ( $200 \mu \mathrm{g}$ q AM or $400 \mu \mathrm{g} \mathrm{q} \mathrm{AM})$ or twice 
daily $(200 \mu \mathrm{g}$ bid ) were compared with placebo. There was significant improvement with both the $200 \mu \mathrm{g}$ bid (16.1\%) and $400 \mu \mathrm{g}$ q AM (16.0\%) dosing over placebo (5.5\%) in mean change from baseline in $\mathrm{FEV}_{1}$. However, the $200 \mu \mathrm{g}$ q AM (10.4\%) dosing did not show a significant difference from placebo. The secondary efficacy variables similarly improved significantly over placebo with a total daily dosing of $400 \mu \mathrm{g}$, whether given as a qd or bid dosing. All the doses were well tolerated.

\section{Once daily versus twice daily dosing in patients previously maintained on ICS}

Noonan et al (2001) randomized 286 mild to moderate asthmatics using twice-daily ICS to receive either MF once daily $(200 \mu \mathrm{g}$ q AM, $200 \mu \mathrm{g}$ q PM or $400 \mu \mathrm{g}$ q AM ) or twice daily ( $200 \mu \mathrm{g}$ bid) or placebo for 12 weeks. This was preceded by a 2-week open-label phase where all subjects received MF $200 \mu \mathrm{g}$ bid. To obtain data on possible HPA axis suppression, cosyntropin stimulation tests were done on 20 to 24 subjects in each treatment group. Results showed that all doses were well tolerated. There was an expected increase in the mean baseline $\mathrm{FEV}_{1}(2.52$ to $2.65 \mathrm{~L})$ after the open-label run-in period on MF $200 \mu \mathrm{g}$ bid. This increase was maintained with the $400 \mu \mathrm{g}$ qd (-0.01), $200 \mu \mathrm{g}$ bid (-0.03), and $200 \mu \mathrm{g}$ q PM (0.03) doses compared with placebo $(-0.30)$. However, the $200 \mu \mathrm{g}$ q AM dose (-0.22) did not do better than placebo, suggesting that evening dosing might be more effective. The $400 \mu \mathrm{g}$ qd dose provided the most consistent improvement in the secondary efficacy variables. The cosyntropin stimulation test results demonstrated that a similar proportion of subjects had normal responses in the treatment and placebo groups. This study was one of the first to show that once-daily dosing could maintain effective control in patients previously on twice-daily dosing.

In a 12-week study with 400 subjects by D'Urzo et al (2005), the primary objective was to compare the efficacy and safety of once-daily MF-DPI $400 \mu \mathrm{g}$ q PM with placebo. A secondary objective was to compare several MF dosing regimens with each other and placebo. Subjects were all previously on stable bid ICS for at least 30 days and were randomized to one of 4 dosing regimens of MF: 200 $\mu \mathrm{g}$ q PM; 2 inhalations of $200 \mu \mathrm{g}$ q PM; $200 \mu \mathrm{g}$ bid; or placebo. All the MF doses showed significant improvement over placebo with mean changes from baseline $\mathrm{FEV}_{1}$ of $0.41 \mathrm{~L}$ (400 $\mu \mathrm{g}$ q PM), 0.49 L (200 $\mu \mathrm{g} 2$ inhalations q PM), 0.41L (200 $\mu \mathrm{g}$ q PM), $0.51 \mathrm{~L}(200 \mu \mathrm{g}$ bid), and $0.16 \mathrm{~L}$ ( placebo) $(p<0.001)$. All of the treatment doses were well tolerated and improved secondary efficacy variables. This study confirmed the efficacy of the $400 \mu \mathrm{g}$ evening dose, whether given as one $400 \mu \mathrm{g}$ inhalation or two $200 \mu \mathrm{g}$ inhalations. The lowest dose of $200 \mu \mathrm{g}$ q PM also appeared to be similarly effective.

Similar results were obtained in a study of 268 subjects by Karpel et al (2005). Patients were 12 years of age or older and previously on stable ICS bid for at least 30 days with $\mathrm{FEV}_{1}$ between $50 \%$ to $85 \%$ of predicted. The treatments in the study included MF $400 \mu \mathrm{g}$ q PM, MF $200 \mu \mathrm{g}$ bid and placebo. Both MF doses were well tolerated with mean change from baseline $\mathrm{FEV}_{1}$ significantly improved over placebo. The once daily MF $400 \mu \mathrm{g}$ was as effective as twice daily MF $200 \mu \mathrm{g}$ bid in improving the primary secondary efficacy measures.

\section{MF in children}

Berger et al (2006) published the results of a study of MF-DPI in 296 asthmatic children. Children were enrolled of 4 to 11 years of age with mild to moderate asthma, an $\mathrm{FEV}_{1}$ of $60 \%$ to $85 \%$ of predicted, and on stable ICS doses for at least 60 days. The subjects were randomized to receive either $100 \mu \mathrm{g}$ once daily in the evening, $100 \mu \mathrm{g}$ bid, or placebo. The authors indicated that the inclusion of a placebo was justified because patients who worsened were to be discontinued and use of short-acting beta-agonists was allowed. Both treatment groups showed significant improvement of $\mathrm{FEV}_{1}$ from baseline compared with placebo $(p \leq 0.002)$. The least squares mean changes in the percentage of predicted $\mathrm{FEV}_{1}$ were 4.73 (MF qd) and 5.52 (MF bid) compared with -1.77 (placebo). There was no significant difference in effectiveness between the two doses $(p=0.70)$. FVC, FEF $25 \%$ to $75 \%$, and PEF were superior for both doses compared with placebo but with no significant difference between the doses. The other secondary variables, including asthma symptom scores, rescue medication use, and HR QoL assessments all showed that the MF groups were similar to each other but superior to placebo. Fewer than $50 \%$ in the MF treatment groups had worsening of asthma so the median time to worsening could not be determined. Overall, this study showed the efficacy and safety of the MF-DPI $100 \mu \mathrm{g}$ once daily evening dosing in children.

\section{Reduction of oral steroids}

\section{in severe asthma}

The use of chronic oral corticosteroids (OCS) is necessary in a small population of patients with severe asthma. Reduction or elimination of OCS use is an important goal in these 
Table I Clinical studies

\begin{tabular}{|c|c|c|c|}
\hline Investigators & Design & Study doses & Results \\
\hline \multicolumn{4}{|l|}{ qd, SABA only } \\
\hline Bensch et al 2006 & $\begin{array}{l}\mathrm{N}=196,12 \text { week, } \mathrm{PC} \text { Primary } \\
\text { outcome: change in } \mathrm{FEV}\end{array}$ & $200 \mu \mathrm{g}$ q AM & $\begin{array}{l}\text { Improvement with } 200 \mu \mathrm{g} \\
(16.8 \%) \text { vs placebo }(6 \%)\end{array}$ \\
\hline Nayak et al 2000 & $\begin{array}{l}\mathrm{N}=236,12 \text { week, } \mathrm{PC} \\
\text { Primary outcome: change } \\
\text { in } \mathrm{FEV}_{\text {, }}\end{array}$ & $\begin{array}{l}200 \mu \mathrm{g} \mathrm{q} \mathrm{AM} \\
400 \mu \mathrm{g} \text { q } \mathrm{AM}\end{array}$ & $\begin{array}{l}\text { Both doses better than placebo but } \\
400 \mu g \text { provided additional } \\
\text { improvement }\end{array}$ \\
\hline \multicolumn{4}{|l|}{ qd vs bid, SABA only } \\
\hline Kemp et al 2000 & $\begin{array}{l}\mathrm{N}=306,12 \text { week, } \mathrm{PC} \text {, Primary } \\
\text { outcome: change in FEV }\end{array}$ & $\begin{array}{l}200 \mu g \text { q } A M, \\
400 \mu g \text { q AM } \\
200 \mu g \text { bid }\end{array}$ & $\begin{array}{l}\text { Total of } 400 \mu g / \text { day effective, either } \\
\text { in qd or bid regimen } \\
\text { Change in FEV, for } 200 \mu \mathrm{g} \text { bid } \\
(16.1 \%), 400 \mu \mathrm{g} \text { qd }(16.0 \%) \\
\text { significant over placebo }(5.5 \%)\end{array}$ \\
\hline \multicolumn{4}{|l|}{ qd vs bid, previous ICS } \\
\hline Noonan et al $200 \mathrm{I}$ & $\begin{array}{l}N=286,12 \text { week, PC, Primary outcome: } \\
\text { change in } F E V_{1}\end{array}$ & $\begin{array}{l}200 \mu \mathrm{g} \text { bid, } \\
200 \mu \mathrm{g} \text { q AM, } \\
200 \mu \mathrm{g} \text { q PM, } \\
400 \mu \mathrm{g} \text { q AM }\end{array}$ & $\begin{array}{l}400 \mu \mathrm{g} q \text { am maintained } \mathrm{FEV}_{1} \text {, lung } \\
\text { function, symptom scores } \\
200 \mu \mathrm{g} q \mathrm{PM} \text { improved } \mathrm{FEV}_{\mathrm{l}} \text {, not } \\
\text { other measures } \\
200 \mu \mathrm{g} \text { q AM not as effective }\end{array}$ \\
\hline D’Urzo et al 2005 & $\begin{array}{l}N=400,12 \text { week, PC, Primary outcome: } \\
\text { change in } F E V_{1}\end{array}$ & $\begin{array}{l}200 \mu \mathrm{g} \text { QD, } \\
400 \mu \mathrm{g} \text { I inhal qd PM } \\
400 \mu \mathrm{g}(2 \text { inhal of } 200 \mu \mathrm{g}) \text { qd PM } \\
200 \mu \mathrm{g} \text { bid }\end{array}$ & $\begin{array}{l}\text { All doses better than placebo, } \\
\text { including lowest dose. Similar } \\
\text { improvement for all doses }\end{array}$ \\
\hline Karpel et al 2005 & $\begin{array}{l}N=268,12 \text { week, PC, Primary outcome: } \\
\text { change in } F E V_{1}\end{array}$ & $\begin{array}{l}400 \mu \mathrm{g} \text { q } \mathrm{PM}, \\
200 \mu \mathrm{g} \text { bid }\end{array}$ & $\begin{array}{l}\text { Both doses better than placebo. } \\
\text { Similar improvement for all doses }\end{array}$ \\
\hline \multicolumn{4}{|l|}{ Pediatric } \\
\hline Berger et al 2006 & $N=296,12$ week, 4-II y.o. & $\begin{array}{l}100 \mu \mathrm{g} \mathrm{q} \mathrm{AM,} \\
100 \mu \mathrm{g} \text { bid }\end{array}$ & $\begin{array}{l}\text { Both doses better than placebo. } \\
\text { Similar improvement for all doses }\end{array}$ \\
\hline \multicolumn{4}{|c|}{ Reduced oral steroids in severe asthma } \\
\hline Fish et al 2000 & $\begin{array}{l}\mathrm{N}=262,12 \text { week } \mathrm{PC} \text { then } \\
9 \text { month open-label }\end{array}$ & $\begin{array}{l}400 \mu \mathrm{g} \text { bid } \\
800 \mu \mathrm{g} \text { bid }\end{array}$ & $\begin{array}{l}\text { OCS reduced by } 46 \% \\
(400 \mu \mathrm{g}), 23.9 \%(800 \mu \mathrm{g}), \\
\text { increased by } 164.4 \% \text { (placebo) } \\
\text { OCS eliminated in } 40 \%(400 \mu \mathrm{g}) \text {, } \\
37 \%(800 \mu \mathrm{g}), 0 \% \text { (placebo) } \\
\text { Lung function and QofL improved }\end{array}$ \\
\hline Karpel et al 2007 & $\begin{array}{l}\mathrm{N}=123,12 \text {-week, } \mathrm{PC} \text { then } \\
\text { 9-month open label }\end{array}$ & $\begin{array}{l}\text { HFA-227 MDI } \\
400 \mu \mathrm{g} \text { bid } \\
800 \mu \mathrm{g} \text { bid }\end{array}$ & $\begin{array}{l}\text { OCS reduced by } 39.4 \% \\
(400 \mu \mathrm{g}), 31.1 \%(800 \mu \mathrm{g}) \text {, } \\
\text { increased by } 107.2 \% \text { (placebo) } \\
\text { OCS reduced by } \geq 50 \% \\
\text { in } 63 \%(400), 60 \%(800), 14 \%(\mathrm{P}) \\
\text { Overall results: (with open } \\
\text { label extension) } 67 \% \text { OCS } \\
\text { reduction, } 5 \text { I\% OCS elimination }\end{array}$ \\
\hline Schmier et al 2003 & Open label extension of Fish et al (2000) & $\begin{array}{l}400 \mu \mathrm{g} \text { bid } \\
800 \mu \mathrm{g} \text { bid }\end{array}$ & $\begin{array}{l}\text { SF-36 HRQL (QofL) maintained } \\
\text { or improved for } 3 \text { months of open } \\
\text { label extension }\end{array}$ \\
\hline \multicolumn{4}{|l|}{ Comparative } \\
\hline Bousquet et al 2000 & $\begin{array}{l}\mathrm{N}=12 \text { week, AC Primary outcome: } \\
\text { change in } \mathrm{FEV}\end{array}$ & $\begin{array}{l}\text { MF } 100,200,400 \mu g \\
\text { bid, BUD } 400 \mu \mathrm{g} \text { bid }\end{array}$ & $\begin{array}{l}\text { MF } 200,400 \text { bid superior to BUD } \\
400 \text { bid; MF } 200=400 \text { bid } \\
\text { Conclusion: total } 400 \mu \mathrm{g} \\
\text { MF/day better than } \\
800 \mu \mathrm{g} \text { BUD/day }\end{array}$ \\
\hline
\end{tabular}

(Continued) 
Table I (Continued)

\begin{tabular}{|c|c|c|c|}
\hline Investigators & Design & Study doses & Results \\
\hline Chervinsky et al 2002 & $\begin{array}{l}\mathrm{N}=395,4 \text { week , PC Dose ranging, Primary } \\
\text { outcome: change in FEV }\end{array}$ & $\begin{array}{l}\text { MF-MDI 56, 200, } 500 \text { pg } \\
\text { bid, BDP I } 68 \mu g \text { bid }\end{array}$ & $\begin{array}{l}\text { MF } 200 \text { pg bid better than MF } 56 \text { pg bid } \\
\text { and BDP I } 68 \mu \mathrm{g} \text { bid } \\
\text { All doses improved lung function, } \\
\text { symptom scores, QOL } \\
\text { No additional benefit from MF } \\
500 \text { pg bid }\end{array}$ \\
\hline Corren et al 2003 & $\begin{array}{l}N=262,8 \text { week, PC Primary outcome: } \\
\text { change in } F E V_{1}\end{array}$ & $\begin{array}{l}\text { MF } 440 \mu g \text { q AM } \\
\text { BUD DPI q AM }\end{array}$ & $\begin{array}{l}\text { MF-DPI }(8.9 \%) \text { superior to BUD } \\
\text { DPI }(2.1 \%) \text { or placebo }(-3.9 \%)\end{array}$ \\
\hline Nathan et al 200I & $\begin{array}{l}\mathrm{N}=227,12 \text { week, PC Primary outcome: } \\
\text { change in } \mathrm{FEV}\end{array}$ & $\begin{array}{l}\text { MF } 100 \mu \mathrm{g} \text { or } 200 \mu \mathrm{g} \text { bid } \\
\text { BDP I } 68 \mu \mathrm{g} \text { bid }\end{array}$ & $\begin{array}{l}\text { All doses better than placebo } \\
\text { MF } 200 \mu g \text { bid most effective }\end{array}$ \\
\hline O'Connor et al 200I & $\begin{array}{l}\mathrm{N}=733,12 \text { week, } \mathrm{AC} \text { Dose-ranging Pri- } \\
\text { mary outcome: change in FEV }\end{array}$ & $\begin{array}{l}\text { MF I00,200, or } 400 \mu \mathrm{g} \text { bid } \\
\text { FP diskhaler } 250 \mu \mathrm{g} \text { bid }\end{array}$ & $\begin{array}{l}\text { All doses improved outcome } \\
\text { MF } 400 \mu \mathrm{g} / \text { day comparable to FP } \\
500 \mu \mathrm{g} \text { per day } \\
\text { MF } 800 \mu \mathrm{g} \text { /day no additional benefit. MF } \\
200 \mu \mathrm{g} / \text { day least effective }\end{array}$ \\
\hline Wardlaw et al 2004 & $\begin{array}{l}\mathrm{N}=167,8 \text {-week, open label, on previous FP } \\
\text { Primary outcome: change in } \mathrm{FEV}_{1}\end{array}$ & $\begin{array}{l}\text { MF } 400 \mu \mathrm{g} \text { q PM } \\
\text { FP MDI } 250 \mu \mathrm{g} \text { bid }\end{array}$ & $\begin{array}{l}\text { "Comparable efficacy" between MF } \\
(4.58 \%) \text { and FP }(6.98 \%)\end{array}$ \\
\hline
\end{tabular}

Abbreviations: $\mathrm{AC}$, active controlled; $\mathrm{BUD}$, budesonide; $\mathrm{FEV}_{\text {, }}$, forced expiratory volume in I second; $\mathrm{PC}$, placebo controlled; $\mathrm{FP}$, fluticasone proprionate; $\mathrm{MDI}$, metered dose inhaler; $M F$, mometasone furoate; $\mathrm{OCS}$; chronic oral corticosteroids.

patients and is often employed as the "gold standard" for new therapies directed at this severe subgroup of asthmatics.

Fish et al (2000) studied the effect of MF in a 12-week study that randomized 132 subjects with severe, OCSrequiring asthma. The subjects were 12 years of age or older who had required daily or alternate-day OCS for asthma control for 5 or more of the 6 months before enrollment with $\mathrm{FEV}_{1} 40 \%$ to $85 \%$ of predicted. The minimum effective prednisone dose was determined for each subject either by previous documentation in the previous 6 months or before screening by the investigator who reduced the dose in a stepwise manner until pulmonary function declined. Subjects receiving a minimum effective prednisone dose of 5 to $30 \mathrm{mg}$ daily or 10 to $60 \mathrm{mg}$ every other day were eligible for the study. After a 2-week run-in period with the subjects continuing their usual ICS and minimum effective prednisone dose, they were randomized to either MF-DPI $400 \mu \mathrm{g}$ bid, MF $800 \mu \mathrm{g}$ bid, or placebo and their pre-study ICS was stopped. The primary outcome measure was the percentage change from baseline in daily prednisone requirement. A significantly larger proportion of subjects on placebo (55\%) compared with those on MF $400 \mu \mathrm{g}$ bid (7\%) and MF $800 \mu \mathrm{g}$ bid (12\%) discontinued due to treatment failure and worsened asthma. The primary outcome measure showed that the MF $400 \mu \mathrm{g}$ bid (-46\%) and MF $800 \mu \mathrm{g}$ bid (-23.9\%) decreased prednisone use very significantly compared with placebo $(+164.4 \%)$
( $\mathrm{p}<0.01$ ). Sixty-two percent of those on MF $400 \mu \mathrm{g}$ bid and $62 \%$ of those on $800 \mu \mathrm{g}$ bid reduced prednisone dose by $50 \%$ compared with $7 \%$ of the placebo group. Complete elimination of prednisone use was seen in $40 \%$ of the MF $400 \mu \mathrm{g}$ bid group and $37 \%$ of the MF $800 \mu \mathrm{g}$ bid group, compared with $0 \%$ in the placebo group. Indices of pulmonary function, symptom scores, and QoL measures were also improved significantly in the MF treatment groups compared with placebo. The increase in prednisone use in the placebo group was expected because the subjects' usual ICS were stopped prior to randomization. The authors noted that this observation supported the presence of true OCS-dependent asthma in this group. Both MF doses were well-tolerated with comparable results between the two MF doses leading the authors to conclude that the MF $400 \mu \mathrm{g}$ bid dose is a safe and effective alternative to OCS in severe asthma. The steroid-sparing benefits of MF were maintained in a 9-month open label extension phase (Schmier et al 2003).

Using similar methods and outcome measures, a more recent trial studied MF (delivered in the hydrofluoroalkane [HFA]-227 metered dose inhaler [MDI] device) in 123 OCS-dependent severe persistent asthmatics (Karpel et al 2007). Subjects were randomized to receive either MF-MDI $400 \mu \mathrm{g}$ bid, MF-MDI $800 \mu \mathrm{g}$ bid, or placebo for 12 weeks followed by a 9-month open label phase. Daily prednisone doses were reduced in those on MF-MDI $400 \mu \mathrm{g}$ 
bid by $39.4 \%$ and $800 \mu \mathrm{g}$ bid by $31.1 \%$ while it increased by $107.2 \%$ in the placebo group $(\mathrm{p}<0.01)$. Oral steroid use was reduced by at least $50 \%$ in the MF-MDI $400 \mu \mathrm{g}$ bid, MF-MDI $800 \mu \mathrm{g}$ bid, and the placebo groups by $63 \%, 60 \%$, and $14 \%$ respectively. Overall, in the 12 -week trial and the 9 -month extension, there was a $67 \%$ reduction in prednisone requirements and $51 \%$ of subjects eliminated oral steroid use in those receiving MF-HFA.

\section{Comparison with budesonide (BUD)}

In a large active-controlled study by Bousquet et al (2000), 730 subjects in 17 countries with moderate persistent asthma on stable ICS for at least 30 days with $\mathrm{FEV}_{1}$ of $60 \%$ to $90 \%$ of predicted, were randomized to one of three doses of MF (100 $\mu \mathrm{g}$ bid , $200 \mu \mathrm{g}$ bid, $400 \mu \mathrm{g}$ bid) or BUD turbohaler $400 \mu \mathrm{g}$ bid. The results showed significantly superior improvement in the primary efficacy variable with MF $200 \mu \mathrm{g}$ bid $(0.16 \mathrm{~L})$ and $400 \mu \mathrm{g}$ bid $(0.16 \mathrm{~L})$ compared with BUD $400 \mu \mathrm{g}$ bid $(0.06 \mathrm{~L})$, which was comparable with the lowest MF dose of $100 \mu \mathrm{g}$ bid $(0.10 \mathrm{~L})$. Secondary parameters reflected the same results. All the treatment doses were well-tolerated. In this study, a total daily dose of MF $400 \mu \mathrm{g}$ appeared to be more effective than a total daily dose of BUD $800 \mu \mathrm{g}$ (Bousquet et al 2000).

Once-daily MF was also compared with once-daily BUD in a placebo-controlled 8-week study by Corren et al (2003). Two hundred and sixty-two subjects with moderate persistent asthma previously on stable bid ICS were randomized to either MF-DPI $440 \mu \mathrm{g}$ q AM, BUD-DPI $400 \mu \mathrm{g}$ q AM, or placebo. The primary efficacy variable was mean change from baseline $\mathrm{FEV}_{1}$. In this study, MF $440 \mu \mathrm{g}$ q AM showed significantly better improvement in mean percentage change in $\mathrm{FEV}_{1}(8.9 \%)$ compared with BUD $400 \mu \mathrm{g}$ q AM $(2.1 \%)$ and placebo $(-3.9 \%)$.

\section{Comparison with beclomethasone diproprionate (BDP)}

In a 4-week dose-ranging study with 395 subjects, several doses of MF given bid by MDI ( $56 \mu \mathrm{g}, 200 \mu \mathrm{g}, 500 \mu \mathrm{g})$ were compared with BDP $168 \mu \mathrm{g}$ bid or placebo (Chervinsky et al 2002). Both drugs in this study were delivered in MDI devices containing chlorofluorocarbon vehicle. Subjects with moderate asthma, with $\mathrm{FEV}_{1} 50 \%$ to $90 \%$, and stable ICS were randomized. All of the ICS treatment groups showed significant improvement of $6 \%$ (56 $\mu \mathrm{g}$ MF), 13\% (200 $\mu \mathrm{g}$ MF), 14\% (500 $\mu \mathrm{g} \mathrm{MF}$ ), and 4\% (BDP) compared with placebo $(-12 \%)$. The results suggested that the MF $200 \mu \mathrm{g}$ bid and MF $500 \mu \mathrm{g}$ bid doses are equivalent with both being superior in efficacy over the BDP $169 \mu \mathrm{g}$ bid dose. All doses were well tolerated.

A longer, 12-week, placebo-controlled study by Nathan et al (2001) enrolled 227 subjects with moderate persistent asthma with $\mathrm{FEV}_{1} 60 \%$ to $90 \%$ already maintained on ICS for at least 30 days. Subjects were randomized to receive either MF-DPI $100 \mu \mathrm{g}$ bid, MF-DPI $200 \mu \mathrm{g}$ bid, BDP-MDI $168 \mu \mathrm{g}$ bid, or placebo. All of the doses were tolerated well. With regard to efficacy, all of the active groups showed significant improvement in $\mathrm{FEV}_{1}$ over placebo $(-0.21 \mathrm{~L})$ ( $\mathrm{p}<0.01$, all comparisons). However, the MF $200 \mu \mathrm{g}$ bid dose showed a 2-fold improvement $(0.25 \mathrm{~L})$ over MF 100 $\mu \mathrm{g}$ bid $(0.12 \mathrm{~L})$ and BDP $168 \mu \mathrm{g}$ bid $(0.11 \mathrm{~L})$. This study shows that MF $200 \mu \mathrm{g}$ bid is more efficacious in improving lung function and symptom scores compared with MF 100 $\mu \mathrm{g}$ bid and BDP-MDI $168 \mu \mathrm{g}$ bid. The authors noted that the DPI produces high dose uniformity because it does not require hand/breath coordination and that this may contribute to better results with the DPI compared with the MDI.

\section{Comparison with fluticasone proprionate (FP)}

A large active-controlled study conducted in 20 countries by O'Connor et al (2001), with 732 subjects, compared the efficacy and safety of MF-DPI with the FP Diskhaler ${ }^{\circledR}$ $250 \mu \mathrm{g}$ bid as the active control. Subjects were already on stable ICS doses for at least 30 days and had baseline $\mathrm{FEV}_{1}$ at $60 \%$ to $90 \%$ of predicted. Subjects received either one of three doses of MF-DPI (100 $\mu \mathrm{g}, 200 \mu \mathrm{g}$, or $400 \mu \mathrm{g}$ bid) or FP Diskhaler $250 \mu \mathrm{g}$ bid. All MF doses and FP improved $\mathrm{FEV}_{1}$ from baseline with a total daily dose of MF $200 \mu \mathrm{g}$ bid dose $(0.16 \mathrm{~L})$ comparable with FP $500 \mu \mathrm{g}$ per day $(0.16 \mathrm{~L})$. MF $100 \mu \mathrm{g}$ bid was the least effective $(0.07 \mathrm{~L})$ while MF $400 \mu \mathrm{g}$ bid $(0.19 \mathrm{~L})$ offered no additional benefit. Greater improvement was also seen in the secondary variables for the MF $200 \mu \mathrm{g}$ and $400 \mu \mathrm{g}$ bid and FP groups compared with the MF $100 \mu \mathrm{g}$ bid group (O’Connor et al 2001).

Wardlaw et al (2004) conducted an open-label 8 week study of 167 subjects with moderate persistent asthma on previously stable FP for at least 30 days. Subjects were required to have an $\mathrm{FEV}_{1}$ of $60 \%$ to $90 \%$ of predicted and were randomized to receive either MF-DPI $400 \mu \mathrm{g}$ q PM or FP MDI $250 \mu \mathrm{g}$ (two $125 \mu \mathrm{g}$ inhalations) bid. Mean changes from baseline $\mathrm{FEV}_{1}$ for the MF-DPI and FP groups were $0.11 \mathrm{~L}(4.58 \%)$ and $0.16 \mathrm{~L}(6.98 \%)$, respectively $(\mathrm{p}=0.35)$. Both drugs were well tolerated, with significantly more subjects who "liked the inhaler a lot" in MF-DPI group 
$(46.8 \%)$ than in the FP group $(22.4 \%)(p=0.01)$. This open label study confirmed comparable efficacy between a total daily dose on MF $400 \mu \mathrm{g}$ q PM and FP $500 \mu \mathrm{g}$ qd.

The most recent comparison between these two inhaled compounds was published by Harnest et al (2008). In this 12 -week non-inferiority trial of patients with moderate-to-severe persistent asthma, there were no significant between-group differences in lung function, rescue medication use, response to therapy, exacerbation rates, or adverse events between MF-DPI $400 \mu \mathrm{g}$ twice daily or FP-DPI $500 \mu \mathrm{g}$ twice daily. Based on these results, these medications appear to be roughly equivalent in effectiveness on a microgram basis.

\section{Safety and tolerability}

In general, the potential for side effects from ICS is small and the benefits far outweigh any risks (National Heart, Lung and Blood Institute 2007). However, local and occasionally systemic side effects may occur with ICS, especially at high doses. Oral candidiasis can be seen and mouth-rinsing after each inhalation should always be strongly advised for patients. Systemic effects such as adrenal suppression, cataracts, glaucoma, and decreased bone mineral density in adults, and adrenal suppression and decreased growth velocity in children are possible with high doses of inhaled steroids but are much less likely than with oral or parenteral steroids.

In clinical studies in both children and adults, MF has been shown to be well tolerated; oral candidiasis was the most frequently observed treatment-related adverse event (Meltzer et al 2006). Studies of HPA axis suppression have revealed only minimal effects by MF. In one study comparing the HPA axis effects of MF and FP, the free plasma concentration producing $50 \%$ urinary cortisol suppression $\left(\mathrm{IC}_{50}\right)$ was similar for both compounds indicating the same potential to cause systemic side effects (Tayab et al 2007). Adrenal suppression as measured by overnight urinary cortisol/creatinine in a study with 21 patients also suggested similar significant suppression by both MF and FP dry powder formulations (Fardon et al 2004). In a study of MF delivered by DPI or MDI, doses of up to $1600 \mu \mathrm{g}$ daily for 28 days showed minimal HPA axis suppression as measured by serum cortisol concentration area under the curve over 24 hours (AUC 24) and consyntropin response test (Affrime et al 2000). In a study comparing MF-DPI $400 \mu \mathrm{g}$ qd with beclomethasone diproprionate (BDP) HFA $200 \mu \mathrm{g} 2$ puffs bid and BDP-CFC $400 \mu \mathrm{g} 2$ puffs bid for 14 days, the serum cortisol AUC24 decreased to a lesser degree with MF than with the two formulations of BDP (Chrousos et al 2005).
Studies of MF effects on bone mineral density (BMD) have been conducted for periods up to 2 years in duration. At the 2-year endpoint, there was no statistically significant in lumbar spine BMD in patients using $400 \mu \mathrm{g}$ bid compared with a placebo group (Mortimer et al 2005).

Decreases in growth velocity may be observed in children taking with ICS but long-term follow-up studies have shown that the expected adult heights are usually achieved (Agertoft and Pedersen 2000; Gulliver et al 2007). The effect of MF on growth in children has been followed for up to 1 year in clinical studies (Skoner et al 2003; Lemanske et al 2004). In a 1-year study, there was no difference in growth velocity between patients taking MF-DPI $100 \mu \mathrm{g}$ qd (6.42 cm/year) and placebo $(6.52 \mathrm{~cm} /$ year $)$, but a slight but statistically significant difference was observed with patients taking $200 \mu \mathrm{g}$ qd $(5.82 \mathrm{~cm} /$ year $)$.

\section{Conclusion}

MF is a potent ICS with strong affinity for the glucocorticoid receptor. It is currently approved for use in 40 countries including the UK and EU down to the age of 4 years. It is well tolerated with no significant adverse side effects seen in post-marketing surveillance different from those known for ICS as a class. The efficacy of MF has been established in large, well-designed studies. Once-daily dosing has been shown to be as effective as twice daily dosing. In patients with persistent asthma on SABA alone, or on previous ICS taken twice-daily, MF has been shown to be superior to placebo in improving lung function, symptom control and quality of life. It has also allowed severe asthmatics to reduce or eliminate OCS from their regimen. MF-DPI once-daily has shown comparable or better efficacy with BDP, BUD, and FP.

\section{Disclosures}

JC has served as a consultant and advisory board member for, and has received research grants from, Schering Plough, the maker of Asmanex. RT has no disclosures to declare.

\section{References}

Affrime MB, Kosoglou T, Thonoor CM, et al. 2000. Mometasone furoate has minimal effects on the hypothalamic-pituitary-adrenal axis when delivered at high doses. Chest, 118:1538-46.

Affrime MB, Kosoglou T. 2001. The pharmacokinetics of mometasone furoate administered by dry powder inhaler following single and multiple dosing in patients with mild to moderate asthma [abstract] J Allergy Clin Immunol, 107:S104.

Agertoft L, Pedersen S. 2000. Effect of long-term treatment with inhaled budesonide on adult height in children with asthma. $N$ Engl $\mathrm{J} \mathrm{Med}$, 343:1064-9.

Bensch GW, Prenner B, Berkowitz R, et al. 2006. Once-daily evening administration of mometasone furoate in asthma treatment initiation. Ann Allergy Asthma Immunol, 96:533-40. 
Berger WE, Milgrom H, Chervinsky P, et al. 2006. Effects of treatment with mometasone furoate dry powder inhaler in children with persistent asthma. Ann Allergy Asthma Immunol, 97:672-80.

Bousquet J, D’Urzo A, Hebert J, et al. 2000. Comparison of the efficacy and safety of mometasone furoate dry powder inhaler to budesonide Turbuhaler. Eur Respir J, 16:808-16.

Chervinsky P, Nelson HS, Bernstein DI, et al. 2002. Comparison of mometasone furoate administered by metered dose inhaler with beclomethasone dipropionate. Int J Clin Pract, 56:419-25.

Chrousos GP, Ghaly L, Shedden A, et al. 2005. Effects of mometasone furoate dry powder inhaler and beclomethasone dipropionate hydrofluoroalkane and chlorofluorocarbon on the hypothalamicpituitary-adrenal axis in asthmatic subjects. Chest, 128:70-7.

Corren J, Berkowitz R, Murray JJ, et al. 2003. Comparison of once-daily mometasone furoate versus once-daily budesonide in patients with moderate persistent asthma. Int J Clin Pract, 57:567-72.

Crim C, Pierre LN, Daley-Yates PT. 2001. A review of the pharmacology and pharmacokinetics of inhaled fluticasone propionate and mometasone furoate. Clin Ther, 23:1339-54.

Derendorf H, Daley-Yates PT, Pierre LN, et al. 2002. Bioavailability and metabolism of mometasone furoate: pharmacology versus methodology. J Clin Pharmacol, 42:383-7.

D’Urzo A, Karpel JP, Busse WW, et al. 2005. Efficacy and safety of mometasone furoate administered once-daily in the evening in patients with persistent asthma dependent on inhaled corticosteroids. Curr Med Res Opin, 21:1281-9.

Fardon TC, Lee DK, Haggart K, et al. 2004. Adrenal suppression with dry powder formulations of fluticasone propionate and mometasone furoate. Am J Respir Crit Care Med, 170:960-6.

Fish JE, Karpel JP, Craig TJ, et al. 2000. Inhaled mometasone furoate reduces oral prednisone requirements while improving respiratory function and health-related quality of life in patients with severe persistent asthma. J Allergy Clin Immunol, 106:852-60.

Gulliver T, Morton R, Eid N. 2007. Inhaled corticosteroids in children with asthma: pharmacologic determinants of safety and efficacy and other clinical considerations. Paediatr Drugs, 9:185-94.

Harnest U, Price D, Howes T, et al. 2008. Comparison of mometasone furoate dry powder inhaler and fluticasone propionate dry powder inhaler in patients with moderate to severe persistent asthma requiring high-dose inhaled corticosteroid therapy: findings from a noninferiority trial. Asthma, 45:215-20.

Karpel JP, Busse WW, Noonan MJ, et al. 2005. Effects of mometasone furoate given once daily in the evening on lung function and symptom control in persistent asthma. Ann Pharmacother, 39:1977-83.

Karpel JP, Nayak A, Lumry W, et al. 2007. Inhaled mometasone furoate reduces oral prednisone usage and improves lung function in severe persistent asthma. Respir Med, 101:628-37.

Karpel JP, Nelson H. 2007. Mometasone furoate dry powder inhaler: a once-daily inhaled corticosteroid for the treatment of persistent asthma. Curr Med Res Opin, 23:2897-911.

Kemp JP, Berkowitz RB, Miller SD, et al. 2000. Mometasone furoate administered once daily is as effective as twice-daily administration for treatment of mild-to-moderate persistent asthma. J Allergy Clin Immunol, 106:485-92.
Lemanske R. Lockey R, Murphy K. 2004. Effects of one year of treatment with mometasone furoate metered dose inhaler (MF-MDI) on growth in children with asthma. Eur Respir J, 24:378s.

Meltzer EO, Wenzel S. 2006. The efficacy and safety of mometasone furoate delivered via a dry powder inhaler for the treatment of asthma. J Asthma, 43:765-72.

Mortimer KJ, Harrison TW, Tattersfield AE. 2005. Effects of inhaled corticosteroids on bone. Ann Allergy Asthma Immunol, 94:15-21.

Nathan RA, Nayak AS, Graft DF. 2001. Mometasone furoate: efficacy and safety in moderate asthma compared with beclomethasone dipropionate. Ann Allergy Asthma Immunol, 86:203-10.

National Heart, Lung and Blood Institute. 2007. National Asthma Education and Prevention Program. Expert Panel Report 3: Guidelines for the Diagnosis and Management of Asthma. Full Report 2007.

Nayak AS, Banov C, Corren J, et al. 2000. Once-daily mometasone furoate dry powder inhaler in the treatment of patients with persistent asthma. Ann Allergy Asthma Immunol, 84:417-24

Noonan M, Karpel JP, Bensch GW, et al. 2001. Comparison of once-daily to twice-daily treatment with mometasone furoate dry powder inhaler. Ann Allergy Asthma Immunol, 86:36-43.

O'Connor B, Bonnaud G, Haahtela T, et al. 2001. Dose-ranging study of mometasone furoate dry powder inhaler in the treatment of moderate persistent asthma using fluticasone propionate as an active comparator. Ann Allergy Asthma Immunol, 86:397-404.

Sahasranaman S, Issar M, Hochhaus G. 2006. Metabolism of mometasone furoate and biological activity of the metabolites. Drug Metab Dispos, $34: 225-33$.

Schmier J, Leidy NK, Gower R. 2003. Reduction in oral corticosteroid use with mometasone furoate dry powder inhaler improves health-related quality of life in patients with severe persistent asthma. J Asthma, 40:383-93.

Skoner D, Dunn M, Lee T. 2003. Effects of mometasone furoate dry powder inhaler on growth velocity and hypothalamic-pitiuitary-adrenal axis function in children with asthma. Am J Respir Crit Care Med, 167:A272.

Tayab ZR, Fardon TC, Lee DK, et al. 2007. Pharmacokinetic/pharmacodynamic evaluation of urinary cortisol suppression after inhalation of fluticasone propionate and mometasone furoate. Br J Clin Pharmacol, 64:698-705

Teng XW, Cutler DJ, Davies NM. 2003. Mometasone furoate degradation and metabolism in human biological fluids and tissues. Biopharm Drug Dispos, 24:321-33.

Valotis A, Högger P. 2004. Significant receptor affinities of metabolites and a degradation product of mometasone furoate. Respir Res, 5:7.

Valotis A, Neukam K, Elert O, Högger P. 2004. Human receptor kinetics, tissue binding affinity, and stability of mometasone furoate. J Pharm Sci, 93:1337-50.

Wardlaw A, Larivee P, Eller J, et al. 2004. Efficacy and safety of mometasone furoate dry powder inhaler vs fluticasone propionate metered-dose inhaler in asthma subjects previously using fluticasone propionate. Ann Allergy Asthma Immunol, 93:49-55. 